DOI https://doi.org/10.18551/rjoas.2020-10.05

\title{
THE EFFECT OF BUDGET CLARITY, PUBLIC PARTICIPATION, AND MANAGERIAL PERFORMANCE ON REGIONAL FINANCIAL TRANSPARENCY AND ACCOUNTABILITY IN EAST LOMBOK DISTRICT OF INDONESIA
}

\author{
Murdhani Lalu Ahmad \\ Institute of Domestic Government, Indonesia \\ E-mail: murdhani.md@gmail.com
}

\begin{abstract}
This study aims to analyze the influence of clarity of budget targets, community participation, and managerial performance on financial transparency and accountability. The results showed that clarity of budget targets did not have a positive and significant effect on the financial accountability of local governments. Clarity of budget targets has a positive and significant effect on the transparency of local government finances. Managerial performance does not have a positive and significant effect on the financial accountability of local governments. Managerial performance has a positive and significant effect on the financial accountability of local governments. Community participation does not have a positive and significant effect on the financial accountability of local governments. Public participation has a positive and significant effect on the transparency of local government finances. Local government financial transparency has a positive and significant effect on local government financial accountability. Clarity of budget targets does not have a positive and significant effect on regional financial accountability through transparency. Managerial performance has a positive and significant effect on regional financial accountability through transparency. Public participation does not have a positive and significant effect on regional financial accountability through transparency.
\end{abstract}

\section{KEY WORDS}

Clarity of budget objectives, managerial performance, community participation, transparency, accountability.

The implementation of regional autonomy is identical to the demand for good governance in the context of effectiveness and efficiency of regional development within the framework of autonomy which requires prerequisites in the form of good and clean governance. The implementation of Good Governance is the main prerequisite for realizing the aspirations of society in achieving the goals and ideals of the Nation and State. The capability of the East Lombok Regency government in managing finances is stated in the APBD which directly or indirectly reflects the ability of the regional government to finance the implementation of governmental tasks, development and community social services. For this reason, evaluation of regional financial management and regional financial financing will greatly determine the position of a regional government.

Based on APBD data for East Lombok Regency for 5 (five) fiscal years, the income position shows that the Balancing Fund still dominates regional revenues compared to PAD. This indicates the high fiscal dependence of the East Lombok Regency government on the Central Government during the 2015-2019 period even though the regional autonomy package has been rolled out, while the desire of the central government in launching budgets to the regions is to form clarity of budget targets.

Clarity of budget targets is the extent to which budget objectives are clearly and specifically defined with the aim that the budget can be understood by the person responsible for achieving the budget target (Suharono and Solichin, 2006). Accountable regional government financial management cannot be separated from the regional government budget.

In the context of local government, clarity of budget targets is also included in the Regional Strategic Plan (Renstrada) and the Regional Development Program (Propeda). So 
that with clear clarity of budget targets, the budget executing apparatus will also be assisted in its realization, this will directly affect the performance of the apparatus. One of the reasons for the ineffectiveness and efficiency of the budget is due to unclear budget targets which resulted in local government officials experiencing difficulties in preparing budget targets. The clarity of budget targets has implications for the leadership, to formulate budgets in accordance with the targets to be achieved by government agencies. Leaders will have enough information to predict the future accurately. Clear budget targets will make it easier for SKPD to prepare budget targets. Furthermore, the budget targets that are prepared will be in accordance with the targets to be achieved by the local government. Therefore, the performance itself is the final result (output) of the organization in accordance with the objectives of the organization, so that regional financial accountability is formed.

Accountability is the government's responsibility to the community related to activities and activities that are its responsibility through the presentation of financial reports, where the public has the right and authority to ask for responsibility as a manifestation of transparency in financial reporting management (Rahayu, 2011).

The phenomenon that can be observed in current financial management is the strengthening of demands for accountability on public institutions, both at the central and regional levels. Accountability can be interpreted as a form of responsibility for the success or failure of the organization's mission in achieving the goals and objectives that have been previously set, through an accountability medium which is carried out periodically.

Lestari (2015) shows that clarity of budget targets, managerial performance and public transparency does not have an impact on the accountability of performance of government agencies. Meanwhile, budget reporting / accountability and control activities affect the performance accountability of government agencies.

Hasibuan (2008) states that the theory of expectation (Expectancy) is an opportunity that is given to occur because of behavior. Zero expectation indicates that there is no possibility that any outcome will emerge after a certain behavior or action has been performed. One positive expectation indicates certainty that a certain result will appear following an action or behavior that has been done. Performance is determined by the goals to be achieved and to do so requires a motive. Without a motive drive to achieve goals, performance will not work. Motivation will be high to the extent that the award received by an individual for high performance meets dominant needs that are consistent with individual goals (Robbins, 2008). Performance within the scope of local government as an illustration of the level of achievement of targets for the vision, mission and strategies of local government agencies that identify the level of success or failure of implementing work programs in accordance with the functions of the agency officials. According to Mangkunegara (2011:67) that performance is the result of work in quality and quantity achieved by an employee in carrying out his duties according to the responsibilities assigned to him. In general, performance can be defined as the result or level of success of a person within a certain period in carrying out duties and authority.

Participation is a person who is consciously involved in social interaction in certain situations (Wazir, 1999). Meanwhile, community participation is that the community is involved in participating in the identification of problems and potentials that exist in the community, choosing and taking the most alternative solutions in dealing with problems, implementing efforts to solve problems and being involved in the process of evaluating changes that occur (Muslimin, 2012).

Transparency in financial management is one of the main indicators emphasized by the government to prevent criminal acts of corruption and in the context of realizing good governance (Good Government). Minister of Home Affairs Regulation (Permendagri) No. 13 of 2006 concerning Regional Financial Management states that transparency is the principle of openness that enables the public to know and get the widest possible access to information about regional finances. In an effort to achieve transparency in financial management, the government enacted Law no. 14 of 2008 concerning Openness of Public Information, which requires every public agency to provide and serve requests for public information in a fast, timely, low cost and simple manner. 
Table 1 - Realization of Apparatus Expenditures, Public Service Expenditures, Production Sharing Expenditures and Unexpected Expenditures for East Lombok Regency 2015-2019 (Million Rupiah)

\begin{tabular}{|c|c|c|c|c|c|c|c|c|c|}
\hline Year & $\begin{array}{l}\text { Operations } \\
\text { Shopping }\end{array}$ & $\%$ & $\begin{array}{c}\text { Capital } \\
\text { Expenditures }\end{array}$ & $\%$ & $\begin{array}{l}\text { Unexpected } \\
\text { Shopping }\end{array}$ & $\%$ & - & $\%$ & Total Shopping \\
\hline 1 & 2 & $3=2: 10$ & 4 & $5=4: 10$ & 6 & $7=6: 10$ & 8 & $9=8: 10$ & 10 \\
\hline 2015 & $1.040 .590,7$ & 86,07 & $274.779,5$ & 22,73 & $4.000,0$ & 0,33 & \begin{tabular}{|l|}
$1.377 .845,1$ \\
\end{tabular} & 113,96 & $1.209 .073,9$ \\
\hline 2016 & $1.290 .079,7$ & 95.08 & $291.413,7$ & 21,48 & $9.000,0$ & 0,67 & $1.590 .493,4$ & 117,22 & $1.356 .878,4$ \\
\hline 2017 & $1.024 .984,1$ & 63,11 & $20.744,5$ & 1,28 & $12.500,0$ & 0,77 & $1.807 .801,1$ & 111,30 & $1.624 .283,5$ \\
\hline 2018 & $1.189 .984,5$ & 71,72 & $226.997,9$ & 13,68 & $3.745,4$ & 0,23 & $1.926 .783,4$ & 116,12 & $1.659 .300,3$ \\
\hline 2019 & $1.273 .429,2$ & 78,18 & $447.396,5$ & 27,47 & $8.000,0$ & 0,50 & $1.982 .058,6$ & 121,69 & $1.628 .825,0$ \\
\hline Total & & 394,2 & & 86,64 & & 2,5 & & 580,23 & \\
\hline Average & & 78,83 & & 17,32 & & 0,50 & & 116,05 & \\
\hline
\end{tabular}

Source: East Lombok Regency in Figures, 2015-2019, processed.

From the table above it can be shown that the proportion of operating expenditure to total regional expenditure in 2015 was 86.07 percent, in 2017 it decreased to 63.11 , but the following year (2015) it increased again to 71.72 percent until 2016. an increase to 78.18 percent or on average the proportion of operating expenditures to total regional expenditures for five years was 78.83 percent. The proportion of capital expenditure to total regional expenditure during the last five years has continued to fluctuate. In 2015, the proportion of capital expenditure to total regional expenditure was 22.73 percent. In 2017 there was a very drastic decrease of only 1.28 percent. Seen on an average basis, the proportion of capital expenditure funds to total regional expenditure since $2015-2019$ is 17.32 percent.

Meanwhile, the proportion of Unexpected expenditure to total regional expenditure also fluctuates as well. Since 2015 the proportion of Unexpected expenditure to total regional expenditure was 0.33 percent, the highest proportion occurred in 2017 at 0.77 percent, then decreased until 2019 the proportion of Unexpected expenditure to total regional expenditure became 0.5 percent. Or on average over the last five years from 2015-2019 the proportion of Unexpected expenditure to regional expenditure was 0.50 percent. Furthermore, the proportion of transfer spending for five years from 2015-2019 has also increased continuously. As an illustration, in 2015 the proportion of transfer expenditure to total regional expenditure was 113.96 percent, which continues to increase until 2019 to 121.69 percent. If viewed on an average basis, the proportion of transfer expenditure to total regional expenditure is 116.05 percent.

Mahayani's research found that all independent variables have an effect on the dependent variable here the independent variables are subjective norms, performance of government officials, clarity of budget objectives and prosocial behavior while the dependent variables are transparency and accountability.

Nasrul Kahpi Lubis' research (2017) on the factors that are financial reporting transparency and its impact on the quality of financial reporting. The results of this study suggest that simultaneously external pressures, environmental uncertainty and management commitment have an effect on financial reporting transparency. Partially external pressure and environmental uncertainty have an effect on transparency of financial reporting, while management commitment has no effect on transparency of financial reporting. Simultaneously external pressures, environmental uncertainty, management commitment and financial reporting transparency have an effect on the quality of financial reporting. Partially, environmental uncertainty, management commitment and financial reporting transparency affect the quality of financial reporting and affect the quality of financial reporting, while external pressure does not affect the quality of financial reporting. External pressures, environmental uncertainty and management commitment affect the quality of financial reporting through transparency of financial reporting. External pressure has a positive and significant effect on the quality of financial reporting through transparency of financial reporting. These results conclude that financial reporting transparency can mediate (intervening) the relationship of external pressures on financial reporting quality.

Research conducted by Eko Setyanto (2018) factors affecting regional financial accountability. The results of the study suggest that apparatus competence has a positive and significant effect on financial accountability. The quality of AIS software has a positive 
and significant effect on financial accountability. The application of SPI has a positive and significant effect on financial accountability. The application of SAP has a positive and significant effect on financial accountability.

\section{METHODS OF RESEARCH}

This type of research is quantitative research. Quantitative research is research that emphasizes theory testing through measuring research variables with numbers and analyzing data using statistical procedures (Indriantoro and Supomo, 2014: 12). Based on the objectives, this research is an explanatory research. Explanatory research or explanatory research is research that aims to test the hypothesis which states a causal relationship between two or more variables (Sukandarrumidi, 2006: 105). The data collection method used in this research is literature study and documentation study. The data and theory in this study are obtained from literature, articles, journals and previous research results that are relevant to research and theoretical basis. Data is also obtained from documentation studies carried out by collecting primary data both from the institutions that produced the data and also from respondents who were the object of research.

Descriptive statistics are statistics that describe the phenomena or characteristics of the data (Hartono, 2014: 195). Descriptive statistics include the presentation of data through tables, graphs and diagrams. Descriptive statistics are used when the researcher only wants to describe the sample data and does not want to make conclusions that apply to the population in which the sample was drawn. Descriptive statistics are also used to compare sample data (Sugiyono, 2014: 207).

The data analysis method used in this research is the PLS-SEM method with the help of the Smart PLS version 3.0 program. PLS - SEM aims to test the predictive relationship between constructs by seeing whether there is a relationship or influence between these constructs (Ghozali and Latan 2015: 19). The choice of PLS-SEM as a data analysis method is because testing can be carried out without a strong theoretical basis, ignoring some of the OLS (Ordinary Least Square) regression assumptions such as data must be normally distributed in a multivariate manner and there is no multicollonierity problem between exogenous variables, and model accuracy parameters prediction seen from the coefficient of determination (R-square) (Ghozali and Latan, 2015: 19). In addition, PLS is also a soft modeling method of analysis because it does not assume that the data must be measured at a certain scale, which means that the number of samples can be small $(<100$ samples or $=$ 30). Evaluation of the structural model or inner model serves to test the relationship between latent constructs (hypothesis testing), done by, among others

$\mathrm{R}$-squares, is the coefficient of determination on endogenous constructs which is used to see the ability of exogenous variables in explaining endogenous variables. According to Chin (1998) in Ghozali and Latan (2015: 78) the R-squares value is 0.67 (good), 0.33 (moderate) and 0.19 (weak). Predictive relevance ( $Q$ square) and Effect size (f square). The effect size ( $f$ square) is calculated as the absolute value of the individual contribution of each exogenous variable to the R-square value of the endogenous variable. Predictive relevance ( $Q$ square) is used to measure how well the value of observations is generated by the model and also its parameter estimation or to find out the predictive capabilities of the blindfolding procedure (Ghozali and Latan 2015: 81). The value of $Q$ square $>0$ indicates that the model has predictive relevance, while $Q$ square $<0$, indicates that the model lacks predictive relevance (Ghozali and Latan, 2015: 81). Furthermore, Ghozali and Latan (2015: 80) state that in relation to $f$ square, changes in $Q$ square (q square) have a relative impact on the structural model, where q square is 0.02 (weak), 0.15 (moderate) and 0, 35 (strong).

\section{RESULTS OF STUDY}

The research results contain research data and analysis of processed research data. Research data can be presented in the form of tables, graphs, pictures, charts, or other data presentation forms. 
Evaluation of the measurement model (outer model) serves to test the validity and reliability of the model. The outer model in this study was evaluated through convergent validity and discriminant validity of the construct-forming indicators and composite reliability and Cronbach alpha for the indicator block. Convergent validity relates to the principle that the gauges (manifest variables) of a construct should be highly correlated. This test is seen from the loading factor value for each construct indicator. The loading factor value range of 0.5 to 0.6 is considered sufficient. PLS Algorithm obtained the following initial results of the research model:

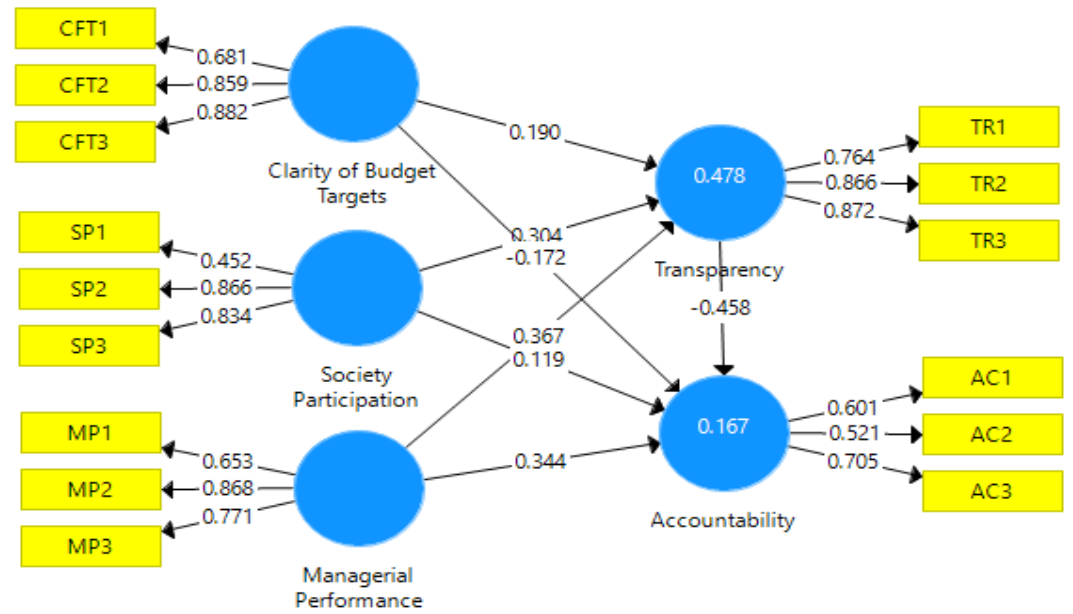

Figure 1 - Result PLS Algorithm Results

The results of the analysis above indicate that the loading factor value of the SP2 and SP3 indicators on the community participation construct has a value greater than 0.5 , namely 0.866 and 0.834 . This means that the SP1 and SP2 indicators can measure the constructs of community participation in this research. On the other hand, the loading factor value of the SP1 indicator does not meet the validity requirements of the community participation construct because it has a value smaller than 0.5 , namely 0.452 . This indicates that the SP1 indicator does not correlate with the construct of community participation so this indicator is dropped from the model. The results of re-estimate the model after removing the SP1 indicator can be seen in the following figure:

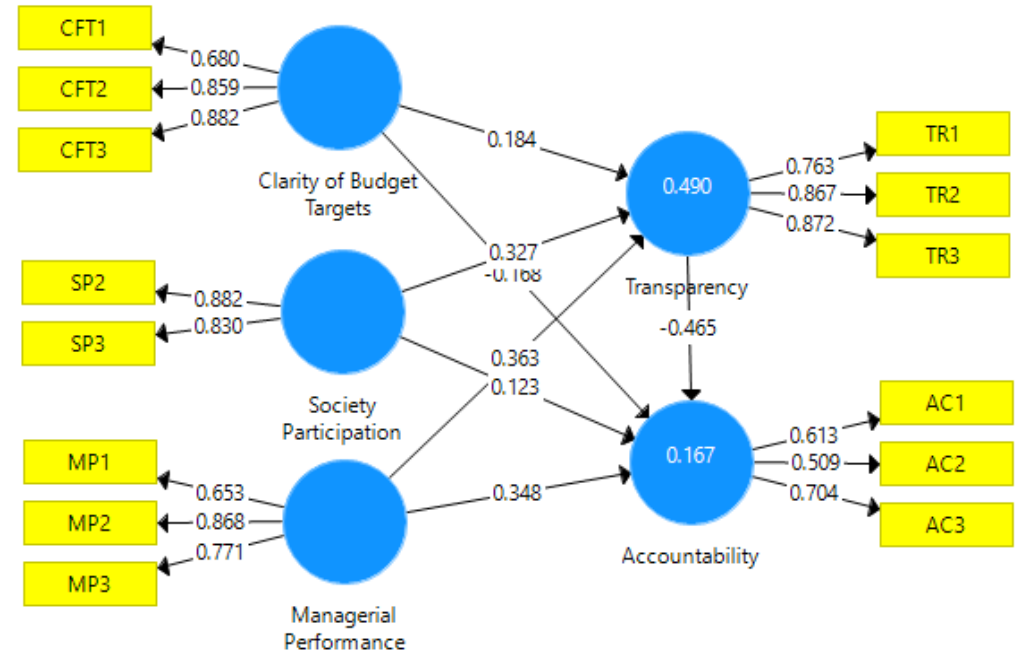

Figure 2 - Results of Re-Estimate Model

The results of re-estimate the model after removing the SP1 indicator make the loading factor values for the SP2 and SP3 indicators of 0.882 and 0.830 . The indicators that form the 
community participation construct have met the convergent validity because the loading factor value is above 0.5. The loading factor value is also supported by the Average Variance Extracted (AVE) value that is greater than 0.5. The R-square value is used to explain the effect of certain exogenous constructs on endogenous constructs whether they have a substantive effect. R-square values of $0.67,0.33$ and 0.19 can be concluded that the model is strong, moderate and weak (Ghozali and Hengky, 2015: 81). The R-square value of the results of the analysis using the bootstrap resampling method at a significance level of 5 percent is presented in Table 1.

Table 2 - R-Square Value

\begin{tabular}{|c|c|c|}
\hline Variable & R Square & R Square Adjusted \\
\hline Accountability & 0,167 & 0,116 \\
\hline Transparency & 0,490 & 0,467 \\
\hline
\end{tabular}

Source: Data processed, 2020.

Based on Table 2, it can be seen that the R-square value of the relationship between the variables of budget target clarity, community participation, and managerial performance on transparency is 0.490 . The R-square value of 0.490 or 49.0 percent belongs to the moderate influence model. This shows that the construct of transparency can be explained by the variables of clarity of budget targets, public participation, and managerial performance by only 49.0 percent. The remaining 51.0 percent is explained by other variables outside the model built in this study. The R-square of the relationship between the variables of budget target clarity, public participation, managerial performance and transparency on accountability is 0.167 . The R-square value of 0.167 or 16.7 percent is classified as a weak influence model. This shows that the accountability construct can be explained by the variables of clarity of budget targets, public participation, managerial performance and transparency, only 16.7 percent. The remaining 84.3 percent is explained by other variables outside the model built in this study.

The effect size is calculated as the absolute value of the individual contribution of each exogenous variable to the R-square value of the endogenous variable. The effect size value for each variable is presented in Table 2 below:

Table 3 - Effect Size Values

\begin{tabular}{|c|c|c|}
\hline Variable & Accountability & Transparency \\
\hline Accountability & - & - \\
\hline Clarity of Budget Targets & 0,022 & 0,045 \\
\hline Managerial Performance & 0,090 & 0,189 \\
\hline Society Participation & 0,012 & 0,154 \\
\hline Transparency & 0,133 & - \\
\hline
\end{tabular}

Source: Data processed, 2020.

The effect size value consists of $0.02 ; 0.15$; and 0.35 . This value illustrates that the predictors of latent variables have small, medium, and large effects at the structural level. Based on Table 2, it can be seen that the clarity of budget targets, public participation, and managerial performance on transparency each contributed $0.045 ; 0.189$; and 0.154 which means that the variable is included in the middle category. Meanwhile, the variables of clarity of budget targets, public participation, managerial performance and transparency towards accountability each contributed $0.022 ; 0.090 ; 0.012$; and 0.133154 which means that the variable is in the weak category.

The Q2 predictive relevance value is used to measure how well the observation value is generated by the model and also its parameter estimation or to know the predictive capability of the blindfolding procedure (Ghozali and Latan 2015: 81). The value of Q2>0 indicates that the model has predictive relevance, while the value of $\mathrm{Q} 2<0$ indicates that the model lacks predictive relevance. The predictive relevance Q2 value is obtained from the following calculations: 


$$
Q^{2}=1-\left(1-R^{2}\right)=0,490
$$

Based on the results of the above calculations, the $Q 2$ predictive relevance value is 0.490 or the Q2 predictive relevance value is $>0$, which means that this research model has predictive relevance. The inner model test is also carried out by looking at the significance value to see the influence between variables. For the significant value of hypothesis support, a comparison of the T-table and T-Statistics values can be used in the estimation results for path coefficient (path coefficient value). If T-statistics is greater than T-table, it means that the hypothesis is supported. The significant value used for the one-tailed hypothesis with a confidence level of 95 percent (alpha 5 percent) is 1.66. In addition, to test the hypothesis, it can be done by analyzing the $p$ value compared to the errors specified in this study, namely one-tailed testing with alpha $5 \%(0.05)$. If $p$ values $<0.05$ means that the hypothesis is accepted but if $p$ values $>0.05$ means that the hypothesis is rejected. The results of the path coefficient analysis are presented in Table 4 below:

Table 4 - Results of Path Coefficient Analysis

\begin{tabular}{|c|c|c|c|}
\hline $\mathrm{n} / \mathrm{n}$ & Original Sample $(\mathrm{O})$ & T Statistics $(|\mathrm{O} / \mathrm{STDEV}|)$ & $\mathrm{P}$ Values \\
\hline Clarity of Budget Targets -> Accountability & $-0,168$ & 0,807 & 0,420 \\
\hline Clarity of Budget Targets - Transparency & 0,184 & 1,965 & 0,050 \\
\hline Managerial Performance -> Accountability & 0,348 & 1,712 & 0,088 \\
\hline Managerial Performance -> Transparency & 0,363 & 3,475 & 0,001 \\
\hline Society Participation -> Accountability & 0,123 & 0,617 & 0,537 \\
\hline Society Participation -> Transparency & 0,327 & 3,242 & 0,001 \\
\hline Transparency -> Accountability & $-0,465$ & 2,731 & 0,007 \\
\hline
\end{tabular}

Source: Data processed. 2020.

The clarity of budget targets is a description of the extent to which budget objectives are clearly and specifically defined with the aim that the budget can be understood by employees who are responsible for achieving these budget targets. In addition, according to Locke in Kurnia (2004), it is said that specific budget targets will be more productive when compared to the absence of specific targets, because it will cause employees to feel confused, depressed, and dissatisfied.

The first hypothesis states that the better the clarity of budget targets, the less accountability to local governments in East Lombok. Table 4 shows that the t-statistic value for the effect of clarity of budget targets on accountability is 0.807 . This value is smaller than the t table value at the 5 percent significance level, namely 1.95, so it can be concluded that the hypothesis is rejected. The $p$ value for the influence of the clarity of budget targets on accountability is 0.420 greater than the alpha value of 0.05 . This means that the relationship between the clarity of budget targets on accountability is not significant, so the hypothesis is rejected. The coefficient value of the clarity of the budget target parameters for accountability is -0.420 with a negative direction. This means that the greater the clarity of budget targets does not have an impact on the level of regional financial accountability.

Clarity of budget targets will help employees to achieve the expected performance, where by knowing the budget targets, the performance level can be achieved. The existence of clear budget targets, it will make it easier to account for the success or failure of the implementation of organizational tasks in order to achieve the goals and objectives that have been previously set. Unclear budget targets will cause budget executors to become confused, uneasy and dissatisfied in their work. This study is not in line with N.L Supadmi's research (2018) which shows that human resource capacity and performance reporting systems have a positive effect on the accountability of village fund management.

The second hypothesis states that the better the clarity of budget targets, the better transparency in local governments in East Lombok. Table 4 shows that the t-statistic value for the effect of clarity of budget targets on accountability is 1.967. This value is greater than the t table value at the 5 percent significance level, namely 1.95, so it can be concluded that the hypothesis is accepted. The $p$ value for the effect of clarity on budget targets on 
transparency is 0.50 as big as the alpha value of 0.05 . This means that the relationship between clarity of budget targets and transparency is significant, so that the hypothesis is accepted. The coefficient value of the clarity of the budget target parameters for transparency is 0.184 in a positive direction. This means that the better the clarity of budget targets, the better the transparency of regional finances.

The results of this study are in line with the stewardship theory in which local governments as stewards are more motivated to achieve organizational goals, in this case, local governments are expected to create transparency towards society in accordance with the expectations and beliefs that have been given by the community. Large local governments have large total assets, so they require close supervision of all government activities. To minimize the asymmetry of financial information with external parties, local governments can publish financial information through the official local government website. The publication of financial information via the internet is also a positive signal given by local governments to the public. This means that the results of this study also support the signaling theory. Clarity of budget targets will help employees to achieve the expected performance, where by knowing the budget targets, the performance level can be achieved. The existence of clear budget targets, it will make it easier to account for the success or failure of the implementation of organizational tasks in order to achieve the goals and objectives that have been previously set. Unclear budget targets will cause budget executors to become confused, uneasy and dissatisfied in their work. This research is not in line with research conducted by Fitri Lestari (2015), which shows that clarity of budget targets, managerial performance and public transparency does not have an impact on the accountability of performance of government agencies. Meanwhile, budget reporting / accountability and control activities affect the performance accountability of government agencies.

The third hypothesis states that the better the managerial performance, the less the accountability to the local government in East Lombok. Table 4 shows that the t-statistic value for the effect of clarity of budget targets on accountability is 1.712 . This value is smaller than the t table value at the 5 percent significance level, namely 1.95, so it can be concluded that the hypothesis is rejected. The $p$ value for the influence of managerial performance on accountability is 0.088 greater than the alpha value of 0.05 . This means that the relationship between managerial performance and accountability is not significant, so the hypothesis is rejected. The coefficient value of managerial performance parameters on accountability is 0.348 in a positive direction. This means that the greater the better the managerial performance, the less impact on regional financial accountability.

The concept of signaling theory illustrates that the government will try to provide positive signals to the public regarding government performance as a form of government accountability. This positive signal can be in the form of disclosure of financial information which is presented in full through the official local government website. The results of this study are in line with the concept of signaling theory in which local governments with good managerial performance tend to establish accountability. The results of this study also do not support the stewardship theory. Local governments are more focused on organizational goals, namely providing services to the community, in this case fulfilling the need for financial information. This research is in line with research conducted by Fitri Lestari (2015), showing that clarity of budget targets, managerial performance and public transparency does not have an impact on the accountability of performance of government agencies. Meanwhile, budget reporting / accountability and control activities affect the performance accountability of government agencies.

The fourth hypothesis states that the better the managerial performance, the better the transparency of the local government in East Lombok. Table 4 shows that the t-statistic value for the effect of clarity of budget targets on accountability is 3,475 . This value is greater than the t table value at the 5 percent significance level, namely 1.95, so it can be concluded that the hypothesis is accepted. The $p$ value for the effect of managerial performance on transparency is 0.50 as big as the alpha value of 0.05 . This means that the relationship between managerial performance and transparency is significant, so that the hypothesis is 
accepted. The coefficient value of the clarity of budget target parameters for accountability is 0.363 with a positive direction. This means that the better the managerial performance, the better the transparency of regional finances.

This is in line with the concept of stewardship theory and signaling theory in which local governments aim to provide services to the public by increasing transparency of financial information through local government websites so that they can be easily accessed by the public anytime and anywhere. Disclosure of financial information through the website is also a positive signal given by the local government to the community, which shows that the local government has carried out the mandate given by the community properly and responsibly.

The fifth hypothesis states that the higher the participation of the community, it does not have an impact on the level of accountability to the local government in East Lombok. Table 4 shows that the t-statistic value for the effect of community participation on accountability is 0.617 . This value is smaller than the $t$ table value at the 5 percent significance level, namely 1.95 , so it can be concluded that the hypothesis is rejected. The $p$ value for the effect of community participation on accountability is 0.537 greater than the alpha value of 0.05 . This means that the relationship between community participation and accountability is not significant, so the hypothesis is rejected. The value of the parameter coefficient of public participation on accountability is 0.123 in a positive direction. This means that the greater the level of community participation does not have an impact on accountability.

Medianti (2018) states that there is an influence from participation on the accountability of village funds, this is evidenced by the increasing community participation, the higher the number of individuals involved in decision making and implementing activities related to community needs. The higher the involvement of these individuals, the higher their sense of responsibility to carry out the decisions that have been produced, and development will be better in the future, the development of a village is said to be good if the results of good village fund management are also. This means that the more intense community participation, the more accountable the management of village funds is.

This research is not in line with the concept of Stewardship theory in which the Government is the steward with the function of managing resources and the people as the principal owner of the resource. An agreement exists between the government (steward) and the people (principal) based on trust, collectively according to organizational goals. In the context of public sector organizations, accountability is the government's obligation as a steward to be accountable for its activities to the people as the principal by disclosing all information, both successes and failures experienced by the organization. Public sector organizations have the aim of providing services to the public and being accountable to the public (public) so that stewardship theory can be applied in the case model of public sector organizations. This is supported by research conducted by Morgan et al., (1996) which states that middle managers in local government are more steward than agents that cause organizational performance to be improved. The results of research conducted by Slyke (2006) also state that government management acts more as a steward because it is influenced by the types of services provided, the level of public management capacity, the types of incentives and sanctions used, and the frequency of information required.

The sixth hypothesis states that the better the community participation, the better the transparency of the local government in East Lombok. Table 4 shows that the t-statistic value for the effect of clarity of budget targets on accountability is 3.242. This value is greater than the t table value at the 5 percent significance level, namely 1.95, so it can be concluded that the hypothesis is accepted. The $p$ value for the influence of clarity of budget targets on transparency is 0.001 smaller with an alpha value of 0.05 . This means that the relationship between public participation and transparency is significant, so that the hypothesis is accepted. The value of the parameter coefficient of public participation on transparency is 0.327 with a positive direction. This means that the better public participation, the better the transparency of regional finances.

This research is in line with the concept (Agency Theory) because of the existence of a relationship between agents and principals. Agents are contracted to perform certain tasks 
for the principal and have responsibility for the duties assigned by the principal. The principal has the obligation to reward the agent for services provided by the agent. The existence of differences in interests between agents and principals is what causes agency conflicts. Principals and agents both want the maximum profit. Principals and agents alike try to avoid risk. This research is in line with Putra (2019). The results of this study indicate that accountability, transparency, and community participation have a positive effect on the effectiveness of village fund management in Abiansemal District, Badung Regency. This shows that the better the accountability, transparency, and community participation, the better the effectiveness of village fund management in Abiansemal District, Badung Regency.

The seventh hypothesis states that the higher the transparency, the higher the level of accountability to the local government in East Lombok. Table 4 shows that the t-statistic value for the effect of transparency on accountability is 2.731 . This value is greater than the $t$ table value at the 5 percent significance level, namely 1.95, so it can be concluded that the hypothesis is accepted. The $p$ value for the effect of transparency on accountability is 0.007 smaller than the alpha value of 0.05 . This means that the relationship between transparency and accountability is significant, so that the hypothesis is accepted. The value of the parameter coefficient of public participation on accountability is -0.465 with a negative direction. This means that the greater the level of transparency has no impact on accountability.

Transparency is the principle that guarantees access or freedom for everyone to obtain information about government administration, namely information about policies, the process of making and the results achieved, it can also be said that transparency is the openness of the government in making policies so that they can be known by the public. In the end, transparency will create accountability between the government and the people (Lalolo 2003: 13). This research is in line with Fitri Lestari's research (2015) which shows that clarity of budget targets, managerial performance and public transparency does not have an impact on the accountability of performance of government agencies. Meanwhile, budget reporting / accountability and control activities affect the performance accountability of government agencies. The concept of accountability also emerged in response to relevant information problems. According to this concept, organizational sustainability is determined by the ability to create quality information, information that is open, balanced and evenly distributed to all interested parties which is reflected in the financial statements. If the control of information is balanced, the parties involved in a transaction / contract can make fair economic decisions.

Table 5 - Total Indirect Effects Value

\begin{tabular}{|c|c|c|c|}
\hline $\mathrm{n} / \mathrm{n}$ & Original Sample $(\mathrm{O})$ & T Statistics $(|\mathrm{O} / \mathrm{STDEV}|)$ & $\mathrm{P}$ Values \\
\hline CFT $>$ TR $>$ AC & $-0,086$ & 1,633 & 0,103 \\
\hline MP $>$ TR $>$ AC & $-0,169$ & 2,280 & 0,023 \\
\hline SP $>$ TR $>$ AC & $-0,152$ & 1,809 & 0,071 \\
\hline
\end{tabular}

Source: Data processed, 2020.

The hypothesis states that the better the clarity of budget targets, the less accountability through financial transparency in local governments in East Lombok. Table 5 shows that the t-statistic value for the effect of clarity of budget targets on accountability through transparency is 1.633. This value is smaller than the table value at the 5 percent significance level, namely 1.95 , so it can be concluded that the hypothesis is rejected. The $p$ value for the influence of clarity of budget targets on accountability through transparency is 0.103 , greater than the alpha value of 0.05 . This means that the relationship between clarity of budget targets and accountability through transparency is not significant, so the hypothesis is rejected. The coefficient value of the clarity of budget target parameters on accountability through transparency is -0.086 with a negative direction. This means that the greater the clarity of budget targets will not have an impact on accountability through transparency of regional finances. 
The hypothesis states that the better the managerial performance, the higher the level of accountability through transparency in the local government in East Lombok. Table 45 shows that the t-statistic value for the effect of managerial performance on accountability through transparency is 2,280 . This value is greater than the table value at the 5 percent significance level, namely 1.95 , so it can be concluded that the hypothesis is accepted. The $p$ value for the effect of managerial performance on accountability through transparency is 0.537 smaller than the alpha value of 0.05 . This means that the relationship between managerial performance and accountability through transparency is significant, so that the hypothesis is accepted. The coefficient value of managerial performance parameters on accountability through transparency is -0.169 with a negative direction. This means that the better the managerial performance, the higher the level of accountability through transparency.

The hypothesis states that the better community participation, the less impact on the level of accountability through transparency in local governments in east Lombok. Table 45 shows that the t-statistic value for the effect of public participation on accountability through transparency is 1.809. This value is smaller than the table value at the 5 percent significance level, namely 1.95 , so it can be concluded that the hypothesis is rejected. The $p$ value for the effect of public participation on accountability through transparency is 0.071 greater than the alpha value of 0.05 . This means that the relationship between public participation and accountability through transparency is not significant, so the hypothesis is rejected. The value of the parameter coefficient of public participation on accountability through transparency is -0.152 with a negative direction. This means that the greater the level of community participation does not have an impact on the level of accountability through transparency.

\section{CONCLUSION}

This study aims to analyze and provide empirical evidence regarding the influence of clarity of budget objectives, community participation, and managerial performance on financial transparency and accountability and to strengthen the relationship between the influence of clarity of budget objectives, community participation, and managerial performance on financial transparency and accountability. Based on the results of the research conducted, the following conclusions can be drawn:

Clarity of budget targets does not have a positive and significant effect on the financial accountability of local governments, meaning that the greater clarity of budget targets does not have an impact on the level of regional financial accountability. Clarity of budget targets has a positive and significant effect on the transparency of local government finances, meaning that the better clarity of budget targets will lead to increased transparency of local government finances. Managerial performance does not have a positive and significant effect on the financial accountability of local governments, meaning that managerial performance does not have an impact on increasing the financial accountability of local governments. Managerial performance has a positive and significant effect on the financial accountability of local governments, meaning that the better managerial performance of the local government will lead to an increase in the level of transparency of local government finances. Community participation does not have a positive and significant effect on the financial accountability of local governments, meaning that community participation does not have an impact on increasing local government financial accountability. Public participation has a positive and significant effect on the transparency of local government finances, meaning that the better public participation will lead to increased financial transparency of local governments.

Local government financial transparency has a positive and significant effect on the financial accountability of local governments, meaning that the better the level of financial transparency of local governments will lead to increased financial accountability of local governments. Clarity of budget targets does not have a positive and significant effect on regional financial accountability through transparency, meaning that the greater clarity of budget targets will not have an impact on accountability through transparency of regional 
finances. Managerial performance has a positive and significant effect on regional financial accountability through transparency. This means that the better the managerial performance, the higher the level of accountability through transparency. Public participation does not have a positive and significant effect on regional financial accountability through transparency. This means that the greater the level of community participation does not have an impact on the level of accountability through transparency.

\section{REFERENCES}

1. Ach. Wazir Ws., et al., ed. (1999). Panduan Penguatan Menejemen Lembaga Swadaya Masyarakat. Jakarta: Sekretariat Bina Desa dengan dukungan AusAID melalui Indonesia HIV/AIDS and STD Prevention and Care Project.

2. Donaldson, L and Davis, J. H. 1991. Stewardship Theory or Agency Theory: CEO Governance and Shareholder Returns. Australian Journal of Management 16: 49-64.

3. Ehrmann Suhartono and Mochammad Solichin (Agustus 2006). Pengaruh Kejelasan Sasaran Anggaran Terhadap Senjangan Anggaran Instansi Pemerintah Daerah Dengan Komitmen Organisasi Sebagai Pemoderasi. Simposium Nasional Akuntansi 9, 23-26.

4. Eko Setyanto (2018) faktor - faktor yang mempengaruhi akuntabilitas keuangan daerah. Jurnal IImiah Akuntansi Volume 9, Nomor 1, hlm 89-105 Januari-April 2018.

5. Enggar; Sri Rahayu; and Wahyudi. 2011. Analisis Efisiensi and Efektivitas Penerimaan Pajak Daerah Propinsi Jambi. Volume 13 No. 1, Fakultas Ekonomi Universitas Jambi Kampus Pinang Masak Mendalo Darat, Jambi.

6. Ghozali, Imam and Hengky Latan. 2015. Partial Least Square: Konsep, Teknik and Aplikasi Menggunakan Program SmartPLS 3.0. Badan Penerbit Universitas Diponegoro.

7. Fitri Lestari (2015), Pengaruh Kejelasan Sasaran Anggaran, Kinerja Manajerial, Pelaporan/ Pertanggungjawaban Anggaran, Transparansi Publik and Aktivitas Pengendalian Terhadap Akuntabilitas Kinerja Instansi Pemerintah.Program Studi Akuntansi FE UMRAH

8. Hartono, Jogiyanto. 2014. Metode Penelitian Bisnis, Salah Kaprah and Pengalamanpengalaman. Edisi Keenam. Yogyakarta: BPFE.

9. Hasibuan, Malayu. 2008. Manajemen Dasar, Pengertian, and Masalah. PT Bumi Aksara.

10. Indriantoro, Nur and Bambang Supomo. 2014. Metode Penelitian Bisnis Untuk Akuntansi \& Manajemen. Cetakan Keenam. Yogyakarta:BPFE.

11. Mangkunegara. 2011. Manajemen Sumber Daya Perusahaan. PT. Remaja Rosdakarya.

12. Muslimin. (2012). Akuntabilitas Pengelolaan Alokasi Dana Desa Di Desa Punagaya Kecamatan Bangkala Kabupaten Jeneponto. Jurnal IImu Pemerintahan Vol.2, No.1.

13. Nasrul Kahpi Lubis (2017) Faktor - Faktor Yang Transparansi Pelaporan Keuangan and Pengaruhnya Terhadap Kualitas Pelaporan Keuangan. Jurnal Riset Akuntansi Going Concern 14(1), 2019, 18-21.

14. Supadmi N.L. (2018) Pengaruh Kapasitas Sumber Daya Manusia, Kejelasan Sasaran Anggaran and Sistem Pelaporan Keuangan Pada Akuntabilitas Pengelolaan Dana Desa Di Kota Denpasar, Vol.13, No.2. 31 Agustus 2018.

15. Staubus, George J.1985. An Induced Theory of Accounting Measurement. The Accounting Review. Vol. LX, No. 1. American Accounting Association.

16. Sugiyono 2014. Metode Penelitian Bisnis. Pendekatan Kuantitatif, Kualitatif and R\&D.

17. Sukandarrumidi. 2006. Metodologi Penelitian Petunjuk Praktis Untuk Peneliti Pemula. Yogyakarta: Gadjah Mada University Press.

18. Susilowati, Harini. 2014. Pengaruh Kejelasan Sasaran Anggaran, Pengendalian Akuntansi, Sistem Pelaporan, and Motivasi Kerja Terhadap Akuntabilitas Kinerja Pemerintah Daerah (Studi Kasus Pada Dinas Pemerintah Kota Surakarta). Skripsi Jurusan Akuntansi pada Fakultas Ekonomi and Bisnis Universitas Muhammadiyah.

19. Syarifudin,Ahmad. 2014. Pengaruh Kompetensi SDM and Peran Audit Intern terhadap Kualitas Laporan Keuangan Pemerintah Daerah dengan Variabel Intervening Sistem Pengendalian Internal Pemerintah. Jurnal Fokus Bisnis, Volume 14, No.02, bulan Desember 2014. 